\title{
Derrida and legal scholarship: a certain step beyond
}

\author{
Derrida and Legal Philosophy, eds. Peter Goodrich, Florian Hoffmann, \\ Michel Rosenfeld, Cornelia Vismann, Basingstoke, Hampshire/New \\ York: Palgrave Macmillan, 2008, 257 p., ISBN-13: 978-o-230-57361-1; \\ ISBN-10: 0-230-57361-4
}

\section{Jacques de Ville}

\section{Introduction}

Derrida and Legal Philosophy follows in the footsteps of only a few other collections which have thus far focused on Derrida's relation to law. These include the Cardozo Law Review of 1990 [1] which contained the papers of the October 1989 Cardozo Law School conference with the theme 'Deconstruction and the Possibility of Justice' and which also included Derrida's paper 'Force of Law: The "Mystical Foundation of Authority". Some of these papers were subsequently published in 1992 in Deconstruction and the Possibility of Justice [2]. After Derrida's death, a conference was again organised, this time by Anselm Haverkamp and Peter Goodrich, at the Cardozo Law School in February 2005 with the theme 'Derrida/America: The Present State of America's Europe' with the papers published in the Cardozo Law Review of 2005 [3]. In the same year, the German Law Journal published a number of essays on Derrida under the editorship of Florian Hoffmann and Cornelia Vismann [4]. The present collection includes some of the essays published in the two law journal issues of 2005 as well as a few other essays. Derrida and Legal Philosophy, as we are informed on the back cover, "traces the path of Derrida's original and provocative legal insights and also maps the geographical and jurisdictional passages of his ideas". In the 'Introduction', we are furthermore informed that the contributors will "endeavor to talk with him [Derrida], to allow him to talk, to give him back speech which the US academy, and at times also the English, German, Spanish and French institutional authorities, sought to silence or to take away" (p. 14). Derrida's texts are complex and the contributors can in principle all be commended for their willingness to engage with these texts, seeing that, as is also pointed out in the 'Introduction', he is completely ignored by many in legal philosophy (p. 9). As will be seen from the assessment that follows, I do not however think that all the contributors are equally successful in this engagement. Some of the contributing authors (including some of the editors) appear to believe - somewhat contrary perhaps to what we are told on the back cover and in the 'Introduction' - that Derrida had no original (legal) insights at all and some even that he is not worth reading by legal scholars or by philosophers. In what follows I will engage briefly, under the same headings as they appear in the book, with each of the 15 essays, plus the 'Introduction', insofar as they relate to Derrida's thinking. For reasons of space, this cannot entail an exhaustive analysis of each essay or of Derrida's texts that are at stake in each instance. 
This review, it should be pointed out here, is not informed by the belief that Derrida cannot or may not be criticised. He surely can, but as the 'Introduction' and Simon Critchley's chapter state, then it must happen rigorously, the pre-requisite being that one must first understand what Derrida's broader 'project' as well as the text(s) in question are about. This review furthermore does not pretend to be the final word on how Derrida and his relation to legal philosophy should be understood. As Derrida also notes in his last interview, accompanied by a smile, "it is only later that all this has a chance of emerging" [5]. At this point, legal philosophy nonetheless needs to at least catch up with what is already understood of Derrida's thinking outside of law, at least in some quarters, as the chapters of Elisabeth Weber as well as that of Avital Ronell reflect so well. There are a number of authors outside of law who have in recent years made a significant contribution to an understanding of Derrida's thinking. I would like to mention here specifically one text each (there are also others) of Rodolphe Gasché [6] Michael Naas [7], Marian Hobson [8], Peggy Kamuf [9], Paola Marrati [10], Hent de Vries [11], Geoffrey Bennington [12] and Sascha Bischof [13]. One can hardly come to grips with Derrida's thinking and its relation to legal philosophy without the assistance of the commentaries of these authors, in addition of course to reading Derrida's texts themselves. The aim of this review is then also to make certain tentative suggestions as to how Derrida's "original and provocative legal insights" could perhaps be taken beyond what is proposed in the book under review, in line with what is already understood regarding his thinking outside of the rather insular legal field. The latter assessment follows from the little appreciation one finds in the legal field of the broader 'project' Derrida is engaged with, that is, to put it very briefly, 'exceeding' the metaphysics of presence. This then leads to interpretations of his texts which are completely at odds with his broader project. A lack of rigorous scholarship seems to be the obvious reason for this, but it may not be fortuitous that it is specifically those who have chosen law as their 'calling' who show such a resistance to that in Derrida's texts which exceeds metaphysics. The possible reasons for this will appear from the further discussion.

The 'Introduction: A Philosophy of Legal Enigmas', co-authored by the four editors, contains some interesting information, including statistics concerning the reception of Derrida in law and of the opposition he as well as those who have sought to follow him, have faced (pp. 6-9). The authors' contention in this regard, which is fully justified in my view, is that "Derrida has not been closely read by those who denounce him" (p. 7). The authors' summary of Derrida's 'thesis' in 'Force of Law: The "Mystical Foundation of Authority" [14, pp. 230-308] is however somewhat surprising in light of all this opposition:

The thesis is that each judgment presents the call of the other; it literally brings the party accused or defended, before the judge. It is the face, the unique and irreducible image of the other, to which the judge must attend and respond. The face has been seen, the voice heard, the pain felt, if pain there be.... The human face is but a figure of the divine; it is properly speaking Aenigmata vultus, a mystery, the visible form of a hidden and absent cause (p. 12). 
The heterogeneity of the above quotation, especially when it refers to "the call of the other" could of course be explored endlessly. This heterogeneity is however quickly tied down in the rest of the quotation and in what follows, as if the editors want to reassure us that Derrida actually said nothing revolutionary at all; he only, as Rosenfeld also contends in his essay, (p. 73), (slightly) disagreed with Aristotle about the importance of the exception in relation to the rule. The question the 'thesis' inevitably raises is whether this really speaks of an original and provocative insight. Is it possible that Derrida's reading of and commentary on all the major thinkers in Western philosophy, including those "dangerous ghosts" Heidegger and Nietzsche that we are referred to (p. 11), not to mention Marx, could ultimately, after Derrida's so-called 'ethical turn', lead only to this 'thesis', which comfortably encloses us back into a metaphysics of presence? This 'thesis' has furthermore plagued scholarship since 'Force of Law' with legal scholars unable to agree whether the 'other' includes all litigants that come to court [15, pp. 113, 143, 152; 16, pp. 1636-1639] or is limited to the 'homeless refugee' [17, pp. 343-369]. Either Derrida hardly had any original insights at all, or the thesis of 'Force of Law' that we are presented with here, and which finds expression in many of the other chapters of this book, requires some rethinking.

\section{Theories}

Simon Critchley presents us with a highly readable chapter titled 'The Reader: Derrida among the Philosophers'. He does not mince his words when challenging those who have dared to criticise Derrida without having read him. Critchley himself has clearly read Derrida and he makes some acute remarks about the relation of Derrida to Heidegger. This brings us back to the point made above. If legal scholars with an interest in Derrida had really studied the relation between the thinking of Derrida and Heidegger, they are unlikely to have so easily concluded what we find in the 'thesis' referred to above. Interestingly enough, however, Critchley appears to agree with legal scholars that 'Force of Law' should be understood in light of "the thought of Emmanuel Levinas and his idea of ethics being based on a relation of infinite responsibility to the other person" (p. 29). There is nonetheless an important difference here compared to the 'thesis' we find in the 'Introduction'. Critchley refers to an "infinite responsibility" of which there is no specific mention in the 'Introduction'. "At the core of Derrida's work", he continues, "functioning as an a priori structure that is not reducible to a ground or foundation, is an experience of justice that is felt in the other's demand" (p. 29). Critchley is furthermore refreshingly honest about (the limits of) his own interest in Derrida's texts, remarking in the first paragraph that he "was never a structuralist and always found Saussure's linguistics a deeply improbable approach to language, meaning and the relation of language and meaning to the world. Therefore Derrida's early arguments in this area, particularly the critique of the priority of speech over writing in the hugely influential $O f$ Grammatology, always left me rather cold" (p. 21). Critchley could of course have been less frank and it may seem somewhat unfair to focus all our attention on this seemingly insignificant remark, but it does turn out to reveal a fault line, closely 
related to the 'thesis' of the ethical turn, that runs not only through his own essay, but throughout many of the chapters of this book. The difficulty that one creates for oneself if one rejects, or decides to not read seriously, Of Grammatology [18], is that there is then little chance that one will understand Derrida's contentions in 'Violence and Metaphysics: An Essay on the Thought of Emmanuel Levinas' [19, pp. 79-153], or what Derrida understands under the "call of the other" (p. 12) and "the other's demand" (p. 29). A reading of this text (as well as the excellent commentary by Naas [7, pp. 93-114]) is essential to understand the not insignificant differences in the thinking between Levinas and Derrida. Although there are also clear overlaps between their thinking - and Critchley's reference to an "infinite responsibility" points in this direction - for Derrida no direct access to the other (or the other's 'face') is possible as it appears to be for Levinas. A belief that it is would for Derrida be informed by a metaphysics of presence. After all, "[t]here is nothing outside of the text", as Derrida remarks famously in Of Grammatology [18, p. 158]. Access to the other (and to the self) is only possible through the mediation of language (also Weber at pp. 178-179). As Of Grammatology and a few of Derrida's other texts on language clearly spell out, this mediation, if analysed rigorously, furthermore involves a drifting, a going outside of the self, an 'experience' of death. This 'experience'- which can never be experienced as such and is therefore also referred to as the experience of the impossible - indeed corresponds with Levinas's notion of 'infinite responsibility' and also with that of absolute hospitality. This is why Derrida can in Adieu [20], after the death of Levinas (and since a debate with him was at this point no longer possible) read him as being in almost complete agreement with his (Derrida's) own hospitable thinking. These seemingly small differences between Levinas and Derrida become crucial in the reading of 'Force of Law', as we will see below. Despite these few, somewhat critical remarks, Critchley's is one of the strongest chapters of this book and one of the few that show an understanding of the broader context of Derrida's reflections on justice.

Duncan Kennedy is one of the legal scholars to have had the longest acquaintance with Derrida's thinking as a 'member' of the critical-legal-studies movement. Kennedy's essay, titled 'European Introduction: Four Objections', is however only very indirectly about Derrida, whose name is invoked in an incidental fashion only twice, and under the rubric of the "post-modern" (p. 33; see also p. 8). The nature of Kennedy's 'reliance' on Derrida comes to the fore when he revealingly charges Europeans for not finding a similar "use" for the work of "the most brilliant, formative characters in their own intellectual tradition", whereas "we have appropriated these famous Europeans [Saussure, Levi-Strauss, Piaget and Derrida are specifically mentioned] for...the American project of radicalizing legal realism" (p. 33). Florian Hoffmann's comment in a later chapter that critical legal studies tend to make instrumental use of deconstruction (p. 192) is openly confessed to here. This instrumental use of deconstruction, as appears from Kennedy's work, can indeed go a long way towards bringing about a more progressive legal system and could for that reason alone be commended from a legal-political perspective (especially when compared with the 'political-liberal' interpretations of Derrida found elsewhere in this book), despite its lack of philosophical rigour. It does however also seem to lead 
to limitations in the 'depth' of the enquiry that Kennedy is engaged with, which he refers to as "part of a broader attempt at a positive sociology of legal knowledge" (p. 37). The question that has to be raised here is whether Derrida's reading of Freud, also in relation to the Oedipus complex, the insights of which are extended to law inter alia in 'Force of Law' [14], does not perhaps provide scope for an even more rigorous analysis of the functioning of what Kennedy refers to as "interpretive communities" (p. 38). As Derrida pertinently notes in For What Tomorrow [21, pp. 179-180], and this is especially the case in politico-legal discourse, "[w]e proceed as if psychoanalysis had never existed.... In an entire zone of our life, we proceed as if, at bottom, we believed in the sovereign authority of the ego, of consciousness, etc., and we speak the language of this 'autonomy."'

Cornelia Vismann's chapter is headed 'The Archive and the Beginning of Law'. The author seeks in this essay to 'disprove' a number of claims she derives from a reading of passages in Derrida's Archive Fever [22, pp. 1-3]. Derrida is for example said to claim that the origins of law are to be found in Greece or the Greek archives (pp. 42, 43, 46, and 50). He is also accused of treating "as parallel [that which] is actually sequential", to be "indifferent to the history of the archives", and to disregard "something in the genesis of the rule of law from the archive which could be called the imperial factor" (p. 44). With reference to Heidegger, Derrida's analysis of the term arkhé is furthermore said to be a "symptom" for an "imperial will to have a beginning", rather than "evidence of a Greek beginning" (p. 46). The contentions of the author that are made here concerning Derrida are completely unjustified. A reading of Archive Fever will show that it primarily deals with the archive in its psychoanalytical sense. There is of course an intimate relation between law and psychoanalysis, but Derrida is hardly concerned here with establishing the origins of law, least of all in Greece or in the Greek archives. He had already enquired into the 'origins' of law in 'Force of Law' and elsewhere and he points out (again) in Archive Fever, as he did in 'Force of Law' [14, p. 235] with his reference to 'To Speculate - On Freud' [23, pp. 257-409], that the importance of psychoanalysis in the deconstruction of law should not be underestimated [22, p. 4]. A reading of Archive Fever, specifically the passages on the death drive which plays such a prominent role here (eg pp. 9-13), as well as Derrida's other engagements with Freud such as Before the Law [24, pp. 181-220], Freud and the Scene of Writing [19, pp. 196-231], and The Postcard [23] should put Vismann on the track of this pre-origin of law.

I find it surprising, in light of the aims of this book, that the editors included the essay of Petra Gehring "The Jurisprudence of the "Force of Law". Instead of "to talk with him, to allow him to talk, to give him back speech" (p. 14), we are told in this essay that Derrida is not worth reading, as what he says hardly makes any sense at all. According to Gehring, the 'procedure' of deconstruction "has a distinctly irritating effect on the reader" (p. 55), what Derrida says about deconstruction and justice "sounds like sophism and it has to provoke philosophical mistrust" (p. 65), 'Force of Law" is as a whole "more likely of interest to philosophers, perhaps only to those specialists in philosophy dealing with the subtle strategies of the self-disclosure which Derrida calls 'deconstruction"” (p. 65), deconstruction involves "a destructive, random intervention in texts which is directed against their declared meanings" (p. 65), 
deconstruction involves "a special form of philosophical redundancy" (p. 66), and with reference to certain passages in 'Force of Law' regarding Benjamin, we are told that "deconstruction can only be regarded as embarrassingly unsuccessful" (p. $70 \mathrm{fn}$ 12). I can continue, but I suspect the point has been illustrated. Although I am furthermore tempted to refute each of these statements and other similar ones in this essay through an elaborate analysis of Derrida's other texts and with reference to the commentaries referred to above, I will merely refer here again to the remarks in the 'Introduction' and also by Simon Critchley about the shocking practice, unfortunately also characterising certain chapters of this book, of criticising Derrida without having closely read him (p. 7).

Michel Rosenfeld 'Derrida's Ethical Turn: The Case of Terrorism', insists despite Derrida's objections, that there was an 'ethical turn' in the latter's thinking (p. 71). The reason for this insistence we find partly in Rosenfeld's summary of Derrida's thinking: "Derrida has always been a philosopher of difference in both its spatial and temporal dimensions; that is, a philosopher of multiplicity and diversity and a philosopher of deferral" (p. 73). Derrida's "ethical turn" then proceeded to accord a "wholly radical role for difference", inscribing itself within the Aristotelian tradition and at the same time turning Aristotle on his head: "For Derrida in every case, justice requires simultaneous compliance with the appropriate universal rule and with its exception, thus making justice both necessary and impossible" (pp. 73-4). It is from the United States, Rosenfeld furthermore asserts, whilst acknowledging that he cannot furnish actual proof for this (p. 74), that Derrida learned about justice as difference (pp. 73-75; 95 fn 12; see also Goodrich at p. 231). The United States has been much more open to difference over the last 25 years than Europe, Rosenfeld contends (p. 71). This is according to the author for example borne out by the progress made in the US to abolish practices of discrimination on the grounds of race, gender and sexual orientation (pp. 73-74). The ethical dimension in Derrida's thinking is to be compared with the European dimension of his thinking (on difference), with Nietzsche and Heidegger being close antecedents (pp. 73 and 75). The question Rosenfeld asks is whether Derrida's ethics of difference and of the other is ultimately possible (p. 72). According to Rosenfeld it is not, because consistently adopting an ethics of difference would mean that one cannot, as Derrida has done, both espouse such a thinking and condemn terrorism, as a 'terrorist' is after all a singular other whose views have to be respected (p. 86: "each claim can only be evaluated from the standpoint of the subjective perspective from which it is made"). Because of this 'failure' in Derrida's thinking, Rosenfeld then proposes an ethics of pluralism.

With the greatest respect to the author, if Derrida's thinking involved simply the espousal of an "ethics of difference" as described in this chapter it would be difficult to understand how anyone having more than a passing acquaintance with philosophy could have regarded him as a philosopher of note or for that matter would write books to honour him. A reading of Of Grammatology [18] and Speech and Phenomena [25], to mention just these two texts, would however show that difference or rather différance is not simply a characteristic of 'reality' or of language for Derrida, but a condition of possibility, that is, what 'produces' differences [25, p. 145; 
27, p. 77]. A reading of these and other texts, specifically those of Derrida on Freud, Heidegger and Nietzsche, would also show that Derrida has no "ontology of singularity" (p. 91, also Thurschwell at p. 161) and that he does not espouse any form of perspectivism [26, p. 78-79]. A reading of these and other texts would furthermore show that there is no "ethical turn" in Derrida's thinking for which the United States can take the credit, but rather that Derrida's non-concept of différance and his later thinking on justice were both formed through a reflection on language and its relation to death through his commentary on the major thinkers in Western philosophy (also Weber at p. 179). Even though Derrida has been influenced in this regard by Freud [23] and Heidegger [27], he is, as will appear from the discussion below, no 'disciple' of Heidegger (as Rosenfeld asserts at p. $95 \mathrm{fn} \mathrm{10}$ ). In his later texts, Derrida refers to this relation with death as 'autoimmunity' [28; 29, pp. 85-136]. Rosenfeld is aware of this notion in Derrida's thinking, but is quick to reject it, asserting the following in this regard (p. 94; see also at pp. 78-79, 82): "If the self attacks itself and becomes its own enemy, and if it cannot avoid harbouring its enemies within itself, then dialogue, accommodation, and any relationship between self and other that is not one of pure enmity become impossible." In this passage we see, as also with the author's contentions regarding difference in Derrida's thinking, an understanding of autoimmunity as a characteristic instead of as a condition of possibility. A reading of Derrida's texts preceding 'Force of Law' such as Speech and Phenomena [25] and Limited Inc [30] would show that what is referred to in the later texts as "autoimmunity" is similarly a conditional feature of language and is what makes a relation to the self and to others possible (also Weber at p. 179). Autoimmunity as Derrida understands it is furthermore closely tied to absolute hospitality. Although Rosenfeld discusses this non-concept in Derrida's thinking fairly accurately (p. 81), he does not take note of the link Derrida posits between justice, absolute hospitality and autoimmunity [28, pp. 141-159]. Justice for Derrida, which is incidentally the impossible ("Justice is an experience of the impossible" [14, p. 244]; see also Krapp at p. 166 and Weber at p. 177) and not simply impossible as Rosenfeld asserts (pp. 73, 75 and 76), therefore does not entail giving in to the claims of every person, but autoimmunity or absolute hospitality of a self in both an individual and a collective sense, in the latter case for example when a 'community' is at stake as it is in the enforcement of law. This is then also why Derrida can say without contradicting himself that there is no future in some versions of Islamic fundamentalism [29, pp. 113-114], because the 'future' he refers to is not the future in a temporal sense (as Rosenfeld thinks, at pp. 84-86), but is closely tied to the death drive which is an always imminent but never present threat and desire [23]. Certain forms of fundamentalism close themselves off as far as possible from this 'future' (the impossible) and can therefore without contradiction be 'condemned' (in a complex move that cannot be elaborated on here) in the name of this future, in the taking of a political stance. Taking such a stance, as Derrida does in Philosophy in a Time of Terror in relation to Islamic 'terrorism', always involves a complex negotiation between the unconditional (justice, hospitality) and the conditional (also Weber at pp. 177-178). At stake here are therefore not simply 'poles' between identity on the one hand and difference on the other, as Rosenfeld asserts (p. 76). 
As in the case of Gehring, I am perplexed about the inclusion of the essay by Friedrich Balke, titled 'Derrida and Foucault on Sovereignty', in this book. After having given some quotations from Rogues [28] (which is incidentally not Derrida's final publication as asserted at pp. 99 and 101) the author declares that he is about to "pose an objection here" (p. 100). The objection is that there is "rather limited political value" in Derrida's theory of sovereignty and the reason for this lies in its "hasty generalization" (p. 100, also at p. 102; compare Weber at p. 179). When someone makes a statement like this about the thinking of a person seemingly important enough to contribute a series of essays to in a book because of his "original and provocative legal insights" as well as statements to similar effect from a number of the other contributors, one would expect some evidence of the author having intensively read not only the text he is engaging with, but a range of texts which have in a sense 'laid the ground' for what Derrida is saying in Rogues, such as Politics of Friendship [31], 'Force of Law' [14], Derrida's texts on hospitality, on forgiveness, and then almost more importantly, his early texts on language as well as those on Freud. The author however provides us with no such evidence, neither in terms of the texts that are cited (the only text of Derrida referred to here, is Rogues) nor in terms of the comments the author makes. A study of Derrida's texts would be able to confirm that Derrida has been engaging with the issue of sovereignty already in 1967, for example in Of Grammatology [18] and Speech and Phenomena [25] through his analysis of subjectivity. What Derrida is saying in Rogues (in 2003), which has been fermenting for decades in a series of publications, cannot therefore possibly be a "hasty generalization", as Balke asserts. Balke later on again professes his perplexity as to what Derrida is saying about sovereignty, and then, revealingly, finds the answer not in a thorough study of Rogues or of Derrida's other texts, which would incidentally have pointed Balke in a different direction, but in Foucault: "What remains unclear in Derrida - that is, in what sense a sovereign could be called a 'rogue' - Foucault reveals" (p. 108, also at p. 101). Incidentally, the summary of Balke's essay (pp. x-xi) is inaccurate. It confuses Rosenfeld's essay with that of Balke. Contrary to what is stated, there is no mention by Balke in his essay of justice and the incalculable.

\section{Disciplines}

Anne Orford in her essay, titled 'Critical Intimacies: Reading International Law', seeks to apply Derrida's thinking within the context of international law. This chapter shows a great deal of insight in relation to Derrida. I nonetheless have a slight disagreement with the author in her attempt to apply Derrida's thinking in The Gift of Death [32] to World Trade Organisation agreements. Here Orford is less complementary, insisting like Rosenfeld on an "ethical turn" in Derrida's thinking, and criticising Derrida for affirming Abraham's response to the absolute demand (of God) placed on him to sacrifice his son, Isaac: "For me, The Gift of Death is the text which has set out the possibilities and limits of this ethical turn most clearly" (p. 117). Orford proceeds to place the market and the demands it makes in the position of the 'absolute other': God's call on Abraham to sacrifice his son. The World Trade Organisation agreement, she contends, demands a sacrifice of "democracy, civility, 
politics, the family of the nation" (p. 118). The sacrifice of Isaac, and to a certain extent, Sarah, in response to the demands of "the Father", the author finds problematic (p. 118). If this assessment were simply based on a reading of Genesis 22, it would have had my support, as this text can clearly be read, applied and problematised in this way. Reading The Gift of Death in this way is problematical for a number of reasons. The position that Derrida accords to the absolute other in his reading of Kierkegaard in The Gift of Death cannot be equated with the demands of "the Father", as the author contends. The essay deals with the call (from the absolute other) for a response beyond economy. Orford knows that this is a feature of many of Derrida's texts, because she states on the first page of her essay that Derrida teaches us "to find the traces of the unique or the singular or the excessive, that which escapes the circle of exchange or the economy of substitution" (p. 115). The (global) market with its inscription in the circle of economic exchange, cannot simply take the place of the absolute other (pp. 117-118). The problem here is the very difficult one of 'the other' or the 'wholly other' (p. 117) in Derrida's texts. Although Derrida refers also to human beings as others, the 'other' from whom the call of absolute responsibility comes in The Gift of Death should, also in light of what was said above, be understood in terms of man's 'relation' to death, the call for one's own death, as happened with Abraham who was called on to offer himself and everything he loved [32, p. 93]. In The Gift of Death Derrida contends that when we give to those who are close to us, we are neglecting other others (humans and/or animals) who are not close to us, and for whom we often care little as they can offer us little in return. The tension lies between our relation with those who are close to us, and those who are not, and who often threaten our internal security. It is therefore not simply a matter of 'when I give to or when a judge decides in favour of one person, another is sacrificed' as this text is often read in a relativistic sense by legal scholars and which to some extent also informs Orford's essay. The absolute call of responsibility, which Abraham heeded, was to not think of himself or those he loved at all, and which Derrida finds 'commendable' in light of his similar reflections on justice, friendship, the gift and hospitality (also Weber at p. 177). The broader point the author tries to make, is nonetheless in line with Derrida's thinking. He is clearly of the view that sovereignty should not simply be abandoned as the state can often resist certain forces, including protecting its citizens from the effects of the global market [21, pp. 91-92]. The problem lies rather in using The Gift of Death in this fashion to make this particular point.

In his chapter with the heading "Il n'y a pas de hors-texte:" Intimations of Jacques Derrida as Comparatist-at-Law', Pierre Legrand invokes Derrida against the orthodoxy of Hein Kötz and his followers in the context of comparative legal studies. It is a good and entertaining read. This is clearly an author with a high regard for Derrida, who has read numerous of his texts and who furthermore shows how some of Derrida's "original and provocative legal insights" can be utilised in the legal context. I have two brief comments to make regarding the essay. The problem that often arises in quoting Derrida (as the author does, extensively) is that what Derrida says often makes sense only when one reads the whole text the quotation comes from, as was also pointed to above. If one has not read these texts of Derrida, quotations by 
another author without a somewhat detailed explanation, often simply lead to bewilderment. The second comment relates to what will be discussed further below regarding singularity and unconditionality in Derrida's work. The author's understanding of justice in Derrida is in my view too much influenced by the orthodox reading of 'Force of Law' which understands Derrida in terms of Levinas (pp. 141-142). The implications of certain passages from Derrida that the author quotes, for example in relation to "the trace" or "the non-legal or pre-legal origin of the legal" (pp. 131-132), and the "logic of haunting at work when it comes to a lawtest" (p. 132) are in my view much more 'radical' than the author thinks and could have a greater 'impact' if the author abandons this orthodox view of what justice entails in Derrida's texts. As also pointed to above, Derrida's references to 'the other' should be understood within the broader context of 'mediation' and the conditions of possibility of such mediation. References to the 'other' should therefore in certain contexts be understood in close connection with the relation to death, the importance of which the author is not unaware of (eg p. $147 \mathrm{fn} \mathrm{59).} \mathrm{I} \mathrm{would} \mathrm{think} \mathrm{that} \mathrm{the}$ implications for comparative legal studies of a thinking of justice in light of the 'other' understood thus, could be significant.

There can be little doubt about the high regard in which Adam Thurschwell holds Derrida and his contribution in this issue, titled 'Specters and Scholars: Derrida and the Tragedy of Political Thought', confirms the serious effort he has made ever since 'Force of Law' to promote Derrida's thinking. Thurschwell unfortunately also adopts the by now orthodox reading of Derrida's reflections on justice as entailing simply the "singularity of an ethical relationship" and an "ethical response to an Other" (p. 154). He sees in this regard, like Rosenfeld, in 'Force of Law' an "irresolvable opposition, or aporia" being posited "between a pole that represents calculative, cognitive, or conceptual knowledge, on one side, and on the other, a pole that represents the singularity of an ethical relationship, demand, or act that cannot be subsumed under any conceptual schema or mode of knowledge" (p. 154). The first point that needs to be made in this regard, which is absolutely essential if one wants to understand 'Force of Law', is that the relation between the "two poles" Thurschwell refers to is not an "opposition" [26, pp. 72-73]. This is clear from the three aporias Derrida discusses in 'Force of Law' and also from the word 'aporia' itself which Derrida does not understand as an opposition, but as "something that does not allow passage. Aporia is a nonpath." [14, p. 244] Mention has already been made above of the relation between the thinking of Levinas and Derrida (see also the insightful comments of Gearey at p. 202). It is necessary to enquire into that relation somewhat further here with reference specifically to the question of singularity. Note should firstly be taken of the numerous qualifications Derrida adds in comparing his notion of justice with that of Levinas [14, p. 250], and which are mostly ignored in commentaries on 'Force of Law'. The passages in 'Force of Law' that are usually relied on in order to make the claim that justice is (simply) a concern with singularity, and which for reasons of space cannot be quoted here, are to be found on page 245 (the first of these is quoted by Weber at p. 178 without however invoking this reductive interpretation). The place of these passages within the broader context of "Force of Law', the appearance in these passages of the words "seem" and "appear", as well as 
the question mark following upon the first of these passages, are however never enquired into when they are relied on to make this claim. One should furthermore not stop here if one wants to understand what Derrida is saying about justice. One should also read the second part of 'Force of Law' where Derrida proceeds to deconstruct the privilege accorded by Benjamin to presence in opposition to representation. Derrida is clearly on page 245 involved with the first of more than one 'phase' in a deconstruction (see also Positions [33, pp. 41-42]) which will culminate not in the positing of a metaphysical opposition between presence and representation (in the form of singularity versus the generality of law), but in the positing of justice as entailing a "gift without exchange, without circulation, without recognition or gratitude, without economic circularity" [14, p. 254], and which stands in an undecidable tension with law [14, pp. 252-255]. This again underlines the danger of relying on passages in Derrida's texts in isolation without an appreciation of the broader context. This ties in with the transformation of the notion of singularity that takes place in 'Force of Law' so that it no longer stands for presence and is no longer in opposition to the generality of law but, as is also pointed out in some of Derrida's other texts, is thought in terms of the unconditional [21, p. 51; 32, pp. 54-81; 34, pp. 12-13]. The orthodox reading of 'Force of Law' ignores completely this move that takes place in 'Force of Law' as well as what Derrida says about a responsibility without limits [14, pp. 247-248]. It turns Derrida's reflections on justice which are closely tied to the thinking of Marx [35] into a position which hardly differs from political liberalism.

A court case is therefore not in the first place about the parties (or a specific party) to the dispute standing opposed to generally applicable law, as the orthodox interpretation of 'Force of Law' has it. Legal decisions (and the same applies to political decisions) are in the first place about unconditional justice, a gift without exchange, and absolute hospitality. This involves an unconditional giving, without expectation of return from the 'community' whose law and protection are at stake. Derrida's thinking can be applied right across the legal field, by taking account of his deconstruction of notions such as equality, dignity, freedom, fraternity, hospitality, forgiveness and democracy [21, pp. 47-61; 28; 31]. Every decision necessarily involves a negotiation between the unconditional and the conditional. By exceeding the circle of exchange in this way, by giving oneself (in an individual or, if applicable, collective sense) over to the impossible decision, a certain step is taken beyond metaphysics, beyond the circle of economic exchange. This does not mean that 'others' do not come into play, but this can happen only in a 'mediated' way as elaborated on above. From a text such as Given Time [36], it for example appears that certain 'others' such as the poor can also represent death, but then again not in the sense of a presence, but in a spectral fashion: "As marginal people excluded from the process of production and circulation of wealth, the poor come to represent the gods or the dead. They occupy the place of the dead man or the spirit, the return of the ghost, that is, of an always imminent threat." [36, p. 138] Justice, as 'Force of Law' furthermore clearly sets out, is not concerned only with human beings. The deconstruction of subjectivity has important implications also for the traditional construction of the man-animal relation [14, pp. 246-247; 37], which the 'thesis' of the 'Introduction' takes no account 
of (p. 9). Deconstruction moreover takes us beyond the traditional legal positivism/natural law debate, with justice, as Derrida conceives of it, 'functioning' as the condition of possibility of both these metaphysical movements.

Peter Krapp 'Between Forgiveness and Forgetting' clearly understands well the relation between Derrida's analysis of forgiveness and that of the gift and justice. He is also one of the few who refers to justice as "an experience of the impossible" (p. 166, my emphasis, also Weber at p. 177). Closely related to the previous remark, he is the only one in this book to remark on the link between forgiveness (and thus by implication also justice) and the Freudian death drive (p. 170). Krapp correctly points to the calculable nature of amnesty and that it should not be confused with (unconditional) forgiveness. The summary of Krapp's essay in the 'Abstracts' section with the remark that "[a]mnesty presents a puzzle as it deviates from the analogous aporias of justice, the gift and forgiveness that lie at the centre of Derrida's ethics" (p. xii), does not on my reading accurately reflect what Krapp says in his essay. Krapp appears not to see amnesty as a 'puzzle', but to understand very well the way in which amnesty involves a calculation in relation to justice as incalculable. Something which the author could perhaps explore in future is the relation between what Derrida says about forgiveness and amnesty and the (criminal) justice system which as Derrida remarks in Specters of Marx [35, p. 25] is based on vengeance and retribution, stemming from the Oedipus complex. Justice, as well as forgiveness, as the author well knows (p. 173) breaks with this cycle of vengeance. The question that arises is whether forgiveness and justice understood thus do not perhaps require of one to go further than the author is prepared to go, that is, viewing "punishment [which] secures the conditions for a free society that protects individual and collective rights" as the normal case, with amnesty being regarded as an exception in defined instances (pp. 171-173). In going beyond this position, a consideration of Freud's thinking, especially in relation to the death drive, would be absolutely essential. As Derrida also remarks in For What Tomorrow [21, p. 179], if psychoanalysis would really seriously be taken account of, as it should, "this would be a nearly unimaginable earthquake. Indescribable. Even for psychoanalysis."

Elisabeth Weber's essay, titled 'Deconstruction is Justice', I regard as the most powerful one in this collection, despite its brevity. It has been referred to a number of times already in this review and little more needs to be said about it here. I am similarly positive about the essay of Florian Hoffmann with the title 'Deadlines: Derrida and Critical Legal Scholarship'. He explores in an excellently written and highly informative essay the link between Derrida's thinking and that of critical legal studies. I am nonetheless slightly hesitant to agree with Hoffmann when he says that justice "is not temporally but spatially remote" (p. 194). As the author well knows, Derrida speaks of justice as "to come" (pp. 194 and 195) and of the gift in terms of an "atemporal temporality" [32, p. 66] which would make of justice 'remote' also in terms of time. This is important in order to understand the Freudian element in deconstruction which if not appreciated, leads to the orthodox understanding of justice pointed to above. This then also relates to the more serious concern I have with another of the author's statements to the effect that "an other - another singularity" is required to appear "before one", for justice to come into play (p. 194). 
The theme of singularity and its relation to justice in Derrida again comes to fore a few pages later where the author speaks of singularities as "the incommunicable substrates of personal epistemologies' (p. 196) which 'cannot be shared intersubjectively". He then also asserts that "[j]ustice on this level is simply the recognition of singularity" (p. 197). The same comments are applicable in this regard as were made above in the context of the 'Introduction' as well as the essays of Rosenfeld and Thurschwell.

Adam Gearey, in his 'Thinking, Poetics, Law' seeks to develop a reading of deconstruction and its relation to law through a reading which departs from the predominantly Levinasian reading that has thus far been given to Derrida in translating his thinking (pp. 202-3, 219). For reasons already pointed to, I think these remarks of Gearey are quite pertinent. Except for the chapter by Critchley, this is the only chapter in which the relation between Heidegger and Derrida is explored to some extent and can for that reason alone be commended. What we find in this essay are acute observations about how Derrida cannot be understood without Heidegger. I nonetheless think that Gearey makes Derrida a little 'too Heideggerian' in this essay. This is to be commended up to a point, especially in light of the reductive reading that is followed in many of the other chapters of this book and elsewhere through the Levinasian reading of Derrida. By perhaps relying a bit too much on Heidegger to understand Derrida, the focus in Gearey however shifts back to Being (p. 219) instead of 'beyond' Being to the gift of Being, or the other of Being, as in Derrida's reading of Heidegger (eg Given Time [36, pp. 18-22, 159-161 fn 28]). This reading of Gearey makes Derrida more concerned with measure (pp. 215, 218), calculation (p. 218) and gathering (which Gearey interestingly links with speech (p. 217)), than with what is immeasurable [28, pp. 42-55] and with disadjustment [35, p. 27]. It would of course be incorrect to say that Derrida is not at all concerned with measure, but there can be no doubt that the emphasis in his thinking and which he seeks to affirm is that from which measure and gathering is derived. In respect of friendship, Derrida's reading of the allegedly Aristotelian phrase " $\mathrm{O}$ my friends, there is no friend" is also, I believe, more transgressive than Gearey contends (p. 216). In Politics of Friendship Derrida speaks of friendship in the same vein in which he speaks of unconditional justice: a friendship that will not be based on sameness and reciprocity, but on dissymmetry [31, p. 63]. Finally, the interpretation Gearey gives to responsibility is for me also an indication that he takes his Heideggerian reading of Derrida in some respects a bit too far (compare in this respect what Derrida [32, pp. 54-81] says on responsibility).

\section{Envoi}

The tributes of Peter Goodrich and Avital Ronell, titled respectively 'Un Cygne Noir' and 'Saying Goodbye: An Amateur Video', are both personal and speak of a wellfounded admiration of Derrida as a person and a scholar. These are not supposed to be chapters that rigorously examine his work and they should of course be read in that spirit. I nevertheless feel the need to remark on one or two comments in the chapter of Goodrich, which also contains some reflections on Derrida's thinking. Goodrich insists, somewhat like Rosenfeld, that it was only upon going to America in 
1989 and his association with the Cardozo Law School that Derrida "digressed from the problematic of existentialism to the political" (p. 231). As has already been pointed out, a reading of Derrida's texts preceding 'Force of Law' does not bear this out. Of Grammatology (1967) [18] with its reflections on the social contract of Rousseau and Glas (1974) [38] with its reflections on Hegel's Philosophy of Right are not at all less concerned with justice (or the political) than 'Force of Law'. The same can be said of Dissemination where Derrida [39, pp. 144-145] already speaks of democracy in much the same way as he would in Rogues; and also of Given Time (based on lectures presented between 1977 and 1978 and which already contains many of Derrida's thoughts on justice. In fact, one can hardly understand what Derrida says on justice unless one carefully studies Given Time. Derrida's 'The Laws of Reflection: Nelson Mandela, in Admiration' [40] which anticipate many of his thoughts in 'Force of Law' also stem from 1987. The reason I am so insistent in this regard is because the notion of an ethical or political turn in Derrida's thinking has led to the unfortunate perception, reflected in many chapters of this book as well as in most of the engagements with 'Force of Law' found elsewhere, that his earlier texts can be ignored, specifically by legal scholars with a concern for justice, because these texts are somehow less ethical or less political. The consequences of this approach are the many misunderstandings in relation to Derrida's thinking that we also find in this collection, including the watered-down Levinasian reading of Derrida, traces of which are also to be found in this chapter (p. 231).

Although I would like to end on a positive and even 'hopeful' note regarding legal scholarship and its relation to Derrida, this may not be very 'realistic'. Unfortunately, this is unlikely to be the last book or other form of engagement with Derrida and his relation to legal philosophy where a reductive reading of his texts dominates or where his thinking is rejected without a close reading. The latter forms of 'engagement' are attractive to legal scholars because, as we know from Derrida's reading of Benjamin in 'Force of Law', law's interest lies in laying itself down and preserving itself [14, pp. 266-267]. As 'servants' of the law, legal scholars through these forms of engagement with Derrida, ensure that this interest of law is not disturbed. This is done by constructing law and its functioning in such a way that it remains comfortably installed within a metaphysics of presence, thereby enabling law to act as a remedy against the fear of death [39, pp. 123-130]. To put it somewhat differently, the interest in self-preservation, a manifestation of the desire for presence, is not original, but consists in a 'repression' of the 'other' desire, the desire for death, which Derrida seeks to affirm. The latter desire, for good reason, appears to be too threatening for most legal scholars to engage with. It is nonetheless only through a rigorous engagement with this desire, an experience of the impossible, that a certain step beyond metaphysics, beyond a circular economy, can be taken. 


\section{References}

1. Derrida, Jacques, et al. 1990. Cardozo Law Review, 11: 919-1726.

2. Derrida, Jacques, et al. 1992. Deconstruction and the Possibility of Justice, eds. Drucilla Cornell, Michel Rosenfeld and David Gray Carlson, New York and London: Routledge.

3. Goodrich, Peter, et al. 2005. Cardozo Law Review, 27: 529-990.

4. Hoffman, Florian, et al. 2005. German Law Journal, 6: 1-199.

5. Derrida, Jacques. 2004. The Last Interview. Available at http://www.studiovisit.net/SV.Derrida.pdf. Accessed 5 January 2009.

6. Gasché, Rodolphe. 1995. Inventions of Difference: on Jacques Derrida, Cambridge, Massachusetts/London: Harvard University Press.

7. Naas, Michael. 2003. Taking on the Tradition: Jacques Derrida and the Legacies of Deconstruction, Stanford: Stanford University Press.

8. Hobson, Marian. 1998. Jacques Derrida: Opening Lines, New York and London: Routledge.

9. Kamuf, Peggy. 2001. Derrida and gender: the other sexual difference. In Jacques Derrida and the Humanities: A Critical Reader, ed. Tom Cohen, 82107. Cambridge: Cambridge University Press.

10. Marrati, Paola. 2005. Genesis and Trace: Derrida Reading Husserl and Heidegger, Stanford: Stanford University Press.

11. De Vries, Henk. 2001. Derrida and ethics: hospitable thought. In Jacques Derrida and the Humanities: A Critical Reader, ed. Tom Cohen, 172-192. Cambridge: Cambridge University Press.

12. Bennington, Geoffrey. 1999. Derridabase. In Jacques Derrida, by Geoffrey Bennington and Jacques Derrida, Chicago: The University of Chicago Press.

13. Bischof, Sascha. 2004. Gerechtigkeit - Verantwortung - Gastfreundschaft: Ethik-Ansätze nach Jacques Derrida, Freiburg, Schweiz/ Freiburg, Wien: Academic Press Fribourg/Verlag Herder.

14. Derrida, Jacques. 2002. Acts of Religion, ed. Gil Anidjar, New York and London: Routledge.

15. Cornell, Drucilla. 1992. The Philosophy of the Limit. New York and London: Routledge.

16. Thurschwell, Adam. 1994. On the Threshold of Ethics. Cardozo Law Review 15: $1607-1655$.

17. Douzinas, Costas. 2000. The End of Human Rights, Oxford and Portland, Oregon: Hart Publishing.

18. Derrida, Jacques. 1976. Of Grammatology, trans. Gayatri Chakravorty Spivak, Baltimore and London: The John Hopkins University Press.

19. Derrida, Jacques. 1978. Writing and Difference, trans, Alan Bass, Chicago: The University of Chicago Press.

20.Derrida, Jacques. 1999. Adieu to Emmanuel Levinas, Stanford: trans. PascaleAnne Brault \& Michael Naas, Stanford University Press.

21. Derrida, Jacques and Elisabeth Roudinesco. 2004. For What Tomorrow...A Dialogue, trans. Jeff Fort, Stanford: Stanford University Press. 
22. Derrida, Jacques. 1995. Archive Fever: A Freudian Impression, trans. Eric Prenowitz, Chicago and London: The University of Chicago Press.

23. Derrida, Jacques. 1987. The Post Card: From Socrates to Freud and Beyond, trans. Alan Bass, Chicago and London: The University of Chicago Press.

24. Derrida, Jacques, 1992. Acts of Literature, ed. Derek Attridge, New York and London: Routledge.

25. Derrida, Jacques. 1973. Speech and Phenomena and Other Essays on Husserl's Theory of Signs, trans. David B Allison, Evanston: Northwestern University Press.

26. Derrida, Jacques. 1999. Questioning Ethics: Contemporary Debates in Philosophy, eds. Richard Kearney and Mark Dooley, New York and London: Routledge.

27. Derrida, Jacques. 1993. Aporias, trans. Thomas Dutoit, Stanford: Stanford University Press.

28. Derrida, Jacques. 2005. Rogues: Two Essays on Reason, trans. Pascale-Anne Brault and Michael Naas, Stanford: Stanford University Press.

29. Borradori, Giovanna. 2003. Philosophy in a Time of Terror: Dialogues with Jürgen Habermas and Jacques Derrida, Chicago and London: The University of Chicago Press.

30.Derrida, Jacques. 1988. Limited Inc, trans. Samuel Weber et al, Evanston: Northwestern University Press.

31. Derrida, Jacques. 1997. Politics of Friendship, trans. George Collins, London and New York: Verso.

32. Derrida, Jacques. 1995, 2008. The Gift of Death, Second Edition \& Literature in Secret, David Wills, trans., Chicago and London: The University of Chicago Press.

33. Derrida, Jacques. 1981. Positions, trans. Alan Bass. Chicago/London: The University of Chicago Press/The Athlone Press.

34. Derrida, Jacques and Maurizio Ferraris. 2001. A Taste for the Secret, trans. Giacomo Donis, Cambridge: Polity Press.

35. Derrida, Jacques. 1994. Specters of Marx: The State of Debt, the Work of Mourning, \& the New International, trans. Peggy Kamuf, New York and London: Routledge.

36. Derrida, Jacques. 1992. Given Time: I. Counterfeit Money, trans. Peggy Kamuf, Chicago and London: University of Chicago Press.

37. Derrida, Jacques. 2008. The Animal that therefore I am, trans. David Wills, New York: Fordham University Press.

38. Derrida, Jacques. 1986. Glas, trans. John P Leavey and Richard Rand, Lincoln and London: University of Nebraska Press.

39. Derrida, Jacques. 1981, 2004. Dissemination, trans. Barbara Johnson, London and New York: Continuum.

40.Derrida, Jacques. 1987. The Laws of Reflection: Nelson Mandela, in Admiration. In For Nelson Mandela, eds. Jacques Derrida \& Mustapha Tlili, New York: Seaver Books. 